\title{
A Study to Predict the Conversion of Laparoscopic To Open Cholecystectomy Using Ultrasound Score
}

\author{
Manivannan .R, Jagadeesh
}

\section{Aims Of The Study}

The aim of this study is to preoperatively predict the conversion of Laparoscopic to open cholecystectomy by using ultrasound scoring the following factors: GB Status, GB Wall thickness, No of stones, Pericholecystic collection, Stone size

\section{Natural History:}

"Most patients with gallstones remain asymptomatic throughout life. Around 3\% of asymptomatic individuals become symptomatic per year and develop biliary colic. Once symptomatic they develop recurrent episodes of biliary colic. Only few patients without biliary symptoms develop complications. Prophylactic cholecystectomy for asymptomatic cholelithiasis is rarely indicated. Elderly patients with diabetes mellitus, individuals who will be isolated from medical care for a prolonged period of time, Gall bladder polyp $>1 \mathrm{~cm}$ are indications for prophylactic cholecystectomy.

\section{Materials And Methods}

A total of 50 cases with gallstones admitted in Rajiv Gandhi govt general hospital, Chennai, during the period from January 2015 to September 2015 and planned for Laparoscopic cholecystectomy were analysed in this study. They were subjected to a detailed history, clinical examination and then to blood investigations and radiological investigations. Their Name, Age, Sex, and findings of USG of Abdomen were recorded. All these patients were subjected to Laparoscopic cholecystectomy the laparoscopic surgery was performed by surgeons at our unit experienced in laparoscopic surgery, therefore, the learning curve statistics do not apply to this study, the operating surgeon was blinded to these findings ,the operative findings were objectively graded as difficult or easy laparoscopic cholecystectomy from insertion of the veress needle or trocar until the extraction of the gall bladder was considered a difficult laparoscopic cholecstectomy, tear of GB, spillage of bile and stones considered a difficult procedure, > 30 minutes taken to dissect GB from GB bed was considered a difficult procedure, > 20 minutes taken to dissect calots triangle was considered difficult procedure,any laparoscopic cholecystectomy converted to the open procedure was considered a difficult laparoscopic cholecystectomy.

\section{Inclusion Criteria:}

- The patients presenting with symptom and sign of cholelithiasis/ diagnosed by ultrasound abdomen.

- Age $20-70$ yrs

Exclusion Criteria:

- Patients below 20yrs age

- Previous abdominal surgery

- Patients with CBD calculus, raised ALP, dilated CBD, where CBD exploration needed.

- Patients with features of obstructive jaundice

- Suspected malignant gall bladder disease

- Patient medically unfit for laparoscopic

\section{Ultrasound Scoring}

\begin{tabular}{|l|l|l|l|l|l|}
\hline & & $\mathbf{1}$ & $\mathbf{2}$ & $\mathbf{3}$ & $\mathbf{4}$ \\
\hline 1 & GB status & normal & Contracted & distended & \\
\hline 2 & GB wall thickness & $<3 \mathrm{~mm}$ & $>3 \mathrm{~mm}$ & & \\
\hline 3 & Number of stones & Single & multiple & & \\
\hline 4 & Pericholcystic collection & no & & $>1 \mathrm{~cm}$ & yes \\
\hline 5 & Stonesize & $<5 \mathrm{~mm}$ & $5 \mathrm{~mm}-1 \mathrm{~cm}$ & \\
\hline
\end{tabular}


Age Distribution:

\section{Results}

A total of 50 patients with clinical and ultrasonographic evidence of gallstones admitted in our hospital were analysed in this study.Of these there were 33 females and 17 males

\begin{tabular}{|l|l|l|l|l|l|}
\hline Sex & & Frequency & Percent & Valid Percent & Cumulative Percent \\
\hline \multirow{3}{*}{ Valid } & $\mathrm{F}$ & 33 & 66.0 & 66.0 & 66.0 \\
\cline { 2 - 6 } & $\mathrm{M}$ & 17 & 34.0 & 34.0 & 100.0 \\
\cline { 2 - 6 } & Total & $\mathbf{5 0}$ & $\mathbf{1 0 0 . 0}$ & $\mathbf{1 0 0 . 0}$ & \\
\hline
\end{tabular}

Gb Status:

\begin{tabular}{|l|l|l|l|l|l|}
\hline Gb Status & \multicolumn{5}{|l|}{ Cumulative Percent } \\
\hline \multirow{3}{*}{ Valid } & DISTENDED & Frequency & Percent & Valid Percent & Cum \\
\cline { 2 - 7 } & NORMAL & 15 & 30.0 & 30.0 & 30.0 \\
\cline { 2 - 6 } & Total & 35 & 70.0 & 70.0 & 100.0 \\
\hline
\end{tabular}

The GB according to ultrasound was found to be distended in $30 \%$ of cases and normal in the remaining $70 \%$ of cases

Gb Wall Thickness

\begin{tabular}{|l|l|l|l|l|l|}
\hline Gb Wall Thickness & Prequency & Percent & Valid Percent & Cumulative Percent \\
\hline \multirow{3}{*}{ Valid } & NO & 37 & 74.0 & 74.0 & 74.0 \\
\cline { 2 - 6 } & YES & 13 & 26.0 & 26.0 & 100.0 \\
\cline { 2 - 6 } & Total & $\mathbf{5 0}$ & $\mathbf{1 0 0 . 0}$ & $\mathbf{1 0 0 . 0}$ & \\
\hline
\end{tabular}

No of Stones:

The ultrasound showed multiple stones in $90 \%$ of cases and single stones were found in $10 \%$ of cases

\begin{tabular}{|c|c|c|c|c|c|}
\hline \multicolumn{6}{|c|}{\begin{tabular}{|l} 
No Of Stones \\
\end{tabular}} \\
\hline & & Frequency & Percent & Valid Percent & Cumulative Percent \\
\hline \multirow[t]{3}{*}{ Valid } & MULTI & 45 & 90.0 & 90.0 & 90.0 \\
\hline & SINGLE & 5 & 10.0 & 10.0 & 100.0 \\
\hline & Total & 50 & 100.0 & 100.0 & \\
\hline
\end{tabular}

\section{Peri Cholecystic Collection}

Pericholecystic collections were found in $22 \%$ of cases and it was not found in $78 \%$ of cases

\begin{tabular}{|l|l|l|l|l|l|}
\hline \multicolumn{5}{|l|}{ Peri Cholecystic Collection } \\
\hline & & Frequency & Percent & Valid Percent & Cumulative Percent \\
\hline \multirow{3}{*}{ Valid } & NO & 39 & 78.0 & 78.0 & 78.0 \\
\cline { 2 - 6 } & YES & 11 & 22.0 & 22.0 & 100.0 \\
\cline { 2 - 6 } & Total & $\mathbf{5 0}$ & $\mathbf{1 0 0 . 0}$ & $\mathbf{1 0 0 . 0}$ & \\
\hline
\end{tabular}

\section{Stone Size}

The stones were found to be $<5 \mathrm{~mm}$ in $92 \%$ of cases, found to be within $5 \mathrm{~mm}$ and $1 \mathrm{~cm}$ in $6 \%$ of cases and $>1 \mathrm{~cm}$ in $2 \%$ of cases

\begin{tabular}{|l|l|l|l|l|l|}
\hline Stone Size & Frequency & Percent & Valid Percent & Cumulative Percent \\
\hline & $>1 \mathrm{~cm}$ & 1 & 2.0 & 2.0 & 2.0 \\
\hline \multirow{4}{*}{ Valid } & $5 \mathrm{~mm}$ to $1 \mathrm{~cm}$ & 3 & 6.0 & 6.0 & 8.0 \\
\cline { 2 - 6 } & $<5 \mathrm{MM}$ & 46 & 92.0 & 92.0 & 100.0 \\
\cline { 2 - 6 } & Total & $\mathbf{5 0}$ & $\mathbf{1 0 0 . 0}$ & $\mathbf{1 0 0 . 0}$ & \\
\hline
\end{tabular}

\section{Score}

\begin{tabular}{|l|l|l|l|l|l|}
\hline Score & \multicolumn{5}{l|}{} \\
\hline \multirow{3}{*}{ Valid } & 6 & Frequency & Percent & Valid Percent & Cumulative Percent \\
\cline { 2 - 6 } & 7 & 28 & 56.0 & 56.0 & 56.0 \\
\cline { 2 - 6 } & 8 & 8 & 16.0 & 16.0 & 72.0 \\
\cline { 2 - 6 } & 9 & 4 & 8.0 & 8.0 & 80.0 \\
\cline { 2 - 6 } & 11 & 3 & 8.0 & 8.0 & 88.0 \\
\cline { 2 - 6 } & 12 & 3 & 6.0 & 6.0 & 94.0 \\
\cline { 2 - 6 } & Total & $\mathbf{5 0}$ & $\mathbf{1 0 0 . 0}$ & $\mathbf{1 0 0 . 0}$ & 100.0 \\
\hline
\end{tabular}


A Study To Predict The Conversion Of Laparoscopic To Open Cholecystectomy Using Ultrasound

\section{Procedure}

\begin{tabular}{|l|l|l|l|l|l|}
\hline Procedure & & Prequency & Percent & Valid Percent & Cumulative Percent \\
\hline \multirow{3}{*}{ Valid } & CONVERTED & 5 & 10.0 & 10.0 & 10.0 \\
\cline { 2 - 7 } & LAP & 45 & 90.0 & 90.0 & 100.0 \\
\cline { 2 - 6 } & Total & $\mathbf{5 0}$ & $\mathbf{1 0 0 . 0}$ & $\mathbf{1 0 0 . 0}$ & \\
\hline
\end{tabular}

\begin{tabular}{|c|c|c|c|c|}
\hline \multicolumn{5}{|l|}{ Crosstab } \\
\hline \multicolumn{5}{|l|}{ Count } \\
\hline & & \multicolumn{2}{|l|}{ PROCEDURE } & \multirow[t]{2}{*}{ Total } \\
\hline & & CONVERTED & LAP & \\
\hline GB STATUS & NORMAL & 0 & 35 & 35 \\
\hline \multicolumn{2}{|l|}{ Total } & 5 & 45 & 50 \\
\hline
\end{tabular}

\begin{tabular}{|c|c|c|c|c|c|}
\hline \multicolumn{6}{|l|}{ Chi-Square Tests } \\
\hline & Value & $\mathrm{df}$ & $\begin{array}{l}\begin{array}{l}\text { Asymp. } \\
\text { sided) }\end{array} \\
\end{array}$ & Exact Sig. (2-sided) & $\begin{array}{l}\text { Exact Sig. (1- } \\
\text { sided) }\end{array}$ \\
\hline Pearson Chi-Square & $12.963^{\mathrm{a}}$ & 1 & .000 & & \\
\hline Likelihood Ratio & 13.413 & 1 & .000 & & \\
\hline Fisher's Exact Test & & & & .001 & .001 \\
\hline McNemar Test & & & & $.002^{\mathrm{c}}$ & \\
\hline
\end{tabular}

a. 2 cells $(50.0 \%)$ have expected count less than 5 . The minimum expected count is 1.50 .

b. Computed only for a $2 \times 2$ table

c. Binomial distribution used.

It was found that of the 35 cases in which the GB status was normal, it was possible to do the surgery in laparoscopy itself . of the remaining 15 cases in which GB was distended, 5 cases were converted to open. The statistical analysis also shows this difference to be significant with a $p$ value of .001

\begin{tabular}{|c|c|c|c|c|}
\hline \multicolumn{5}{|l|}{ Crosstab } \\
\hline \multicolumn{5}{|l|}{ Count } \\
\hline & & \multicolumn{2}{|l|}{ PROCEDURE } & \multirow[t]{2}{*}{ Total } \\
\hline & & CONVERTED & LAP & \\
\hline \multirow[t]{2}{*}{ GB WALL THICKNESS } & $<3 \mathrm{~mm}$ & 0 & 37 & 37 \\
\hline & $>3 \mathrm{~mm}$ & 5 & 8 & 13 \\
\hline \multicolumn{2}{|l|}{ Total } & 5 & 45 & 50 \\
\hline
\end{tabular}

\begin{tabular}{|c|c|c|c|c|c|}
\hline \multicolumn{6}{|l|}{ Chi-Square Tests } \\
\hline & Value & df & Asymp. Sig. (2-sided) & $\begin{array}{lll}\text { Exact } & \text { Sig. } \\
\text { sided })\end{array}$ & 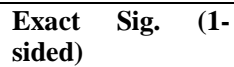 \\
\hline Pearson Chi-Square & $15.812^{\mathrm{a}}$ & 1 & .000 & & \\
\hline Continuity Correction $^{\mathrm{b}}$ & 11.827 & 1 & .001 & & \\
\hline Likelihood Ratio & 15.185 & 1 & .000 & & \\
\hline Fisher's Exact Test & & & & .001 & .001 \\
\hline McNemar Test & & & &. & \\
\hline $\mathrm{N}$ of Valid Cases & 50 & & & & \\
\hline
\end{tabular}

It was found that of the 37 cases in which the GB wall thickness was $<3 \mathrm{~mm}$, it was possible to do the surgery in laparoscopy itself . of the remaining 13 cases in which GB was thickened , 5 cases were converted to open. The statistical analysis also shows this difference to be significant with a $p$ value of .001

\begin{tabular}{|c|c|c|c|c|}
\hline \multicolumn{5}{|c|}{ Crosstab } \\
\hline & & Count & \multirow{2}{*}{ Total } \\
\hline & & PONVERTED & LAP & \\
\hline \multirow{2}{*}{ NO OF STONES } & MULTI & 4 & 41 & 45 \\
\cline { 2 - 5 } & SINGLE & 1 & 4 & 5 \\
\hline \multicolumn{2}{|c|}{ Total } & $\mathbf{5}$ & $\mathbf{4 5}$ & $\mathbf{5 0}$ \\
\hline
\end{tabular}




\begin{tabular}{|c|c|c|c|c|c|}
\hline \multicolumn{6}{|l|}{ Chi-Square Tests } \\
\hline & Value & df & $\begin{array}{l}\text { Asymp. Sig. (2- } \\
\text { sided) }\end{array}$ & $\begin{array}{lll}\text { Exact } & \text { Sig. } \\
\text { sided })\end{array}$ & $\begin{array}{lll}\text { Exact } & \text { Sig. } \\
\text { sided })\end{array}$ \\
\hline Pearson Chi-Square & $.617^{\mathrm{a}}$ & 1 & .432 & & \\
\hline Continuity Correction $^{b}$ & .000 & 1 & 1.000 & & \\
\hline Likelihood Ratio & .508 & 1 & .476 & & \\
\hline Fisher's Exact Test & & & & .423 & .423 \\
\hline McNemar Test & & & &.$^{\mathrm{c}}$ & \\
\hline $\mathrm{N}$ of Valid Cases & 50 & & & & \\
\hline \multicolumn{6}{|c|}{ a. 3 cells $(75.0 \%)$ have expected count less than 5 . The minimum expected count is .50 . } \\
\hline \multicolumn{6}{|c|}{ b. Computed only for a $2 \times 2$ table } \\
\hline \multicolumn{6}{|c|}{ c. Both variables must have identical values of categories. } \\
\hline
\end{tabular}

It was found that of the 45 cases in which the multiple stones were found, 4 cases were converted .of the remaining 5 cases in which single stones were found , 1 cases were converted to open. The statistical analysis also shows this difference to be significant with a $\mathrm{p}$ value of .423 . This suggests that in this study number of stones alone is not a significant factor to predict conversion into open.

\begin{tabular}{|c|c|c|c|c|c|c|c|c|}
\hline \multicolumn{8}{|l|}{ Crosstab } & \\
\hline \multicolumn{8}{|l|}{ Count } & \\
\hline & & & \multicolumn{4}{|c|}{ PROCEDURE } & \multirow[t]{2}{*}{ Total } & \\
\hline & & & \multicolumn{2}{|c|}{ CONVERTED } & \multicolumn{2}{|l|}{ LAP } & & \\
\hline \multirow{2}{*}{\multicolumn{2}{|c|}{$\begin{array}{l}\text { PERI CHOLECYSTIC } \\
\text { COLLECTION }\end{array}$}} & $\mathrm{NO}$ & \multicolumn{2}{|l|}{0} & \multicolumn{2}{|l|}{39} & 39 & \\
\hline & & YES & \multicolumn{2}{|l|}{5} & \multicolumn{2}{|l|}{6} & 11 & \\
\hline \multicolumn{3}{|l|}{ Total } & \multicolumn{2}{|l|}{5} & \multicolumn{2}{|l|}{45} & 50 & \\
\hline \multicolumn{9}{|l|}{ Chi-Square Tests } \\
\hline & \multicolumn{2}{|c|}{ Value } & df & \multicolumn{2}{|c|}{$\begin{array}{l}\text { Asymp. Sig. } \\
\text { (2-sided) }\end{array}$} & \multicolumn{2}{|c|}{$\begin{array}{l}\text { Exact Sig. (2- } \\
\text { sided) }\end{array}$} & $\begin{array}{l}\text { Exact Sig. (1- } \\
\text { sided) }\end{array}$ \\
\hline Pearson Chi-Square & \multicolumn{2}{|c|}{$19.697^{\mathrm{a}}$} & 1 & \multicolumn{2}{|c|}{.001} & & & \\
\hline Continuity Correction $^{\mathrm{b}}$ & \multicolumn{2}{|c|}{14.970} & 1 & \multicolumn{2}{|l|}{.001} & & & \\
\hline Likelihood Ratio & \multicolumn{2}{|c|}{17.350} & 1 & \multicolumn{2}{|l|}{.001} & & & \\
\hline Fisher's Exact Test & & & & & & .001 & & .001 \\
\hline McNemar Test & & & & & &.$^{\mathrm{c}}$ & & \\
\hline $\mathrm{N}$ of Valid Cases & 50 & & & & & & & \\
\hline \multicolumn{9}{|c|}{ a. 2 cells $(50.0 \%)$ have expected count less than 5 . The minimum expected count is 1.10 . } \\
\hline \multicolumn{9}{|c|}{ b. Computed only for a $2 \times 2$ table } \\
\hline \multicolumn{9}{|c|}{ c. Both variables must have identical values of categories. } \\
\hline
\end{tabular}

It was found that of the 39 cases in which pericolecystic collection was not there, it was possible to do the surgery in laparoscopy itself . of the remaining 11 cases had pericholecystic collection, 5 cases were converted to open. The stastistical analysis also shows this difference to be significant with a $p$ value of .001

\begin{tabular}{|c|c|c|c|c|}
\hline \multicolumn{5}{|l|}{ Crosstab } \\
\hline \multicolumn{5}{|l|}{ Count } \\
\hline & & \multicolumn{2}{|l|}{ PROCEDURE } & \multirow[t]{2}{*}{ Total } \\
\hline & & CONVERTED & LAP & \\
\hline \multirow[t]{4}{*}{ STONE SIZE } & 1X.5CM & 0 & 1 & 1 \\
\hline & $1 \mathrm{X} 1 \mathrm{CM}$ & 0 & 1 & 1 \\
\hline & 1X1CM & 2 & 0 & 2 \\
\hline & $5 \mathrm{MM}$ & 3 & 43 & 46 \\
\hline \multicolumn{2}{|l|}{ Total } & 5 & 45 & 50 \\
\hline
\end{tabular}

\begin{tabular}{|c|c|c|c|}
\hline \multicolumn{4}{|l|}{ Chi-Square Tests } \\
\hline & Value & df & $\begin{array}{l}\text { Asymp. Sig. (2- } \\
\text { sided) }\end{array}$ \\
\hline Pearson Chi-Square & $11.433^{\mathrm{a}}$ & 2 & .003 \\
\hline Likelihood Ratio & 6.509 & 2 & .039 \\
\hline $\mathrm{N}$ of Valid Cases & 50 & & \\
\hline
\end{tabular}


Bar Chart

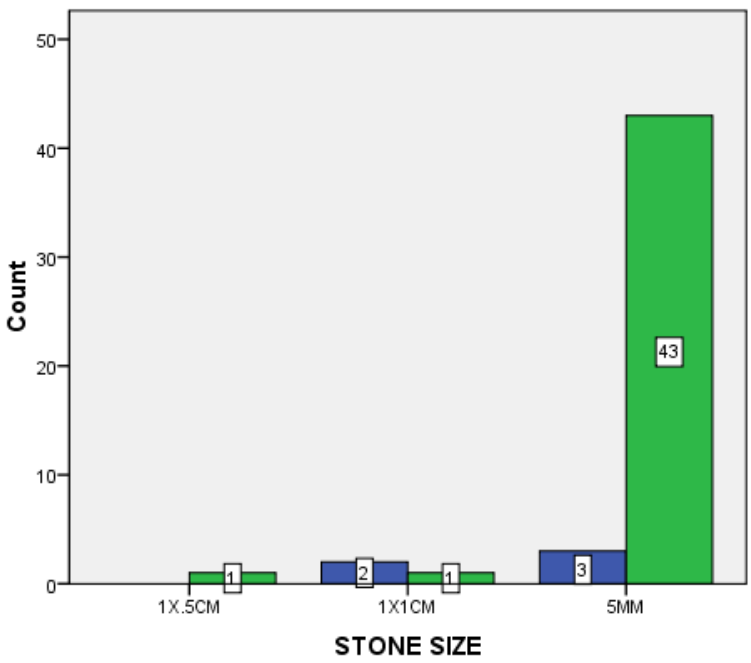

PROCEDURE

GCONVERTED in which stones were between $5 \mathrm{~mm}$ and $1 \mathrm{~cm}, 2$ cases were converted to open. The one case with a stone more than $1 \mathrm{~cm}$ was done by laparoscopy, The statistical analysis also shows this difference to be significant with a $\mathrm{p}$ value of .003

\begin{tabular}{|c|c|c|c|c|}
\hline \multicolumn{5}{|c|}{ Crosstab } \\
\hline \multicolumn{5}{|l|}{ Count } \\
\hline & & \multicolumn{2}{|l|}{ PROCEDURE } & \multirow{2}{*}{ Total } \\
\hline & & CONVERTED & LAP & \\
\hline \multirow[t]{6}{*}{ SCORE } & 6 & 0 & 28 & 28 \\
\hline & 7 & 0 & 8 & 8 \\
\hline & 8 & 0 & 4 & 4 \\
\hline & 9 & 0 & 4 & 4 \\
\hline & 11 & 3 & 0 & 3 \\
\hline & 12 & 2 & 1 & 3 \\
\hline Total & & 5 & 45 & 50 \\
\hline
\end{tabular}

\begin{tabular}{|l|l|l|l|}
\hline Chi-Square Tests & Value & df & Asymp. Sig. (2-sided) \\
\hline Pearson Chi-Square & $42.593^{\mathrm{a}}$ & 5 & .001 \\
\hline Likelihood Ratio & 28.689 & 5 & .001 \\
\hline McNemar-Bowker Test &. &. &. \\
\hline N of Valid Cases & 50 & &. \\
\hline a. 10 cells (83.3\%) have expected count less than 5. The minimum expected count is .30. \\
\hline b. Computed only for a PxP table, where P must be greater than 1. \\
\hline
\end{tabular}

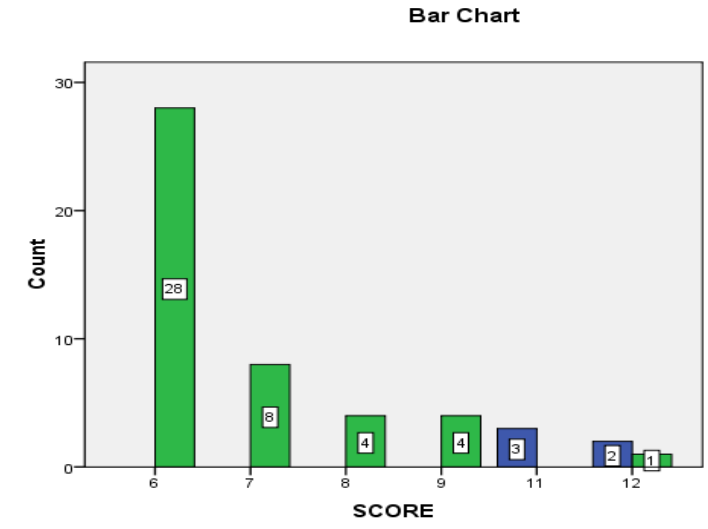


It can be noted that as the score increases the chance of the case being opened increases and all the opened cases had score of either 11( 3 cases) or 12(2 cases). The statistical analysis also shows the difference to be significant with a $p$ value of .001

\section{Discussion}

Laparoscopic cholecystectomy has become the gold standard treatment for patients with gallstones due to less morbidity, lesser hospital stay and early return to normal activities. The difficult gallbladder is the most common 'difficult' laparoscopic surgery being performed by general surgeons all over the world and the potential one that places the patient at significant risk ${ }^{12}$. Previous reports have promulgated the use of scoring systems to predict conversion to open cholecystectomy. However, these systems presented incongruent data points, evaluated a limited number of factors, included subjective variables, and some were formulated early in the course of laparoscopic cholecystectomy before the operation became uniformly established ${ }^{16}$. So we planned to analyse USG factors to predict the conversion of laparoscopic cholecystectomy to open cholecystectomy.

In our study, 50 patients diagnosed with gallstones were taken for Laparoscopic cholecystectomy. Among the 50 patients, 33 patients( i.e. 66\%) were female and 17 patients (i.e. $34 \%$ ) were male. Of the 50 patients, 5 patients were converted to open cholecystectomy.

\section{GB status}

It was found that of the 35 cases in which the GB status was normal, it was possible to do surgery in laparoscopic itself, of the remaining 15 cases in which GB was distended , 5 cases were converted to open , the statistical analysis also shows this difference to be significant with a p value of 0.001

\section{GB wall thickness}

It was found 37 cases with GB wall thickness was $<3 \mathrm{~mm}$ possible to do laparoscopic itself , remaining 13 cases GB wall thickness was $>3 \mathrm{~mm}$, of which 5 cases were converted to open, the statistical analysis also shows this difference to be significant with a p value of 0.001

\section{Number of stones}

it was found 45 casesin which the multiple stones found, 4 cases were converted, of the remaining 5 cases in which single stones were found, 1 cases were converted to open, the statistical analysis also shows this difference to be significant with a pvalue of 0.423 this suggest that in this study number of stones alone is not a significant factor to predict conversion to open

\section{Pericholecystic collection}

It was found that of the 39 cases in which pericholecystic collection was not there, it was possible to do the surgery in laparoscopic itself.

Of the remaining 11 cases had pericholecystic collection, of which 5 cases were converted to open The statistical analysis also shows this difference to be significant with a $\mathrm{P}$ value of 0.001 .

\section{Stone size}

It was found that of the 46 cases in which stones were $<5 \mathrm{~mm}$, 3 cases were converted.

Of the 3 cases in which stones were between $5 \mathrm{~mm}$ and $1 \mathrm{~cm}$,
2 cases converted to open.

The one case with a stone more than $1 \mathrm{~cm}$ was done by laparoscopy, the statistical analysis also shows this difference to be significant with a $P$ value of 0.003

A, Echogenic foci in the gallbladder with acoustic shadowing (S) are characteristic of gallstones. In this patient, the gallbladder wall is thickened.. Features suggest chronic cholecystitis. B, Multiple stones are layered in the dependent portion of the gallbladder, but the wall is not thickened.

Gallbladder wall thickness more than $3 \mathrm{~mm}$ was found to be a risk factor for conversion in many studies. Hutchinson et al(2008), Liu et al considered gallbladder wall thickness to be the most important sonographic risk factor for conversion to open cholecystectomy.

Gallbladder wall thickness is related to the inflammation or fibrosis that follows previous attacks of cholecystitis and thus may reflect difficulty in delineation of anatomy during surgery. Similarly prolonged operating time was demonstrated in patients with Gallbladder wall thickness of more than $3 \mathrm{~mm}$.

This may be due to difficulty during grasping the gallbladder, difficult Gallbladder bed dissection and higher incidence of bleeding ${ }^{20}$. Our study also demonstrated that increased Gallbladder wall thickness is associated with increased risk of conversion to open cholecystectomy.

Many studies have considered gallbladder thickness as a significant risk factor for conversion to open cholecystectomy. In our study also it was found that increased gallbladder wall thickness of more than $3 \mathrm{~mm}$ was associated with increased risk of conversion to open cholecystectomy.

The presence of pericholecystic collection renders the dissection of calot's triangle difficult and 
increased chances of conversion to open cholecystectomy ${ }^{11}$.

In our study we analysed USG factors such as GB status, GB wall thickness, number of stones, pericholecystic collection, size of stone as the USG score increases the chance of the case being opened increases and all the opened cases had either 11 or 12 ,

The statistical analysis also shows the difference to be significant with a p value of 0.001

\section{Conclusion}

Laparoscopic cholecystectomy has gradually replaced open cholecystectomy in the treatment of patients with benign gallbladder disease. With the advancement in equipment and experience in laparoscopic surgery, most of the difficult gallbladder can be dealt laparoscopically.

Preoperative USG examination of the GB is a good predictor of difficult cholecystectomy in majority of cases and should be used pre operatively as a routine screening tool to delineate biliary tree anatomy and pathology, pre operative risk factor can help to predict difficult gallbladder and conversion to other type of cholecystectomy.

In our study we analysed USG factors such as GB status, GB wall thickness, number of stones, pericholecystic collection, size of stone.

In our study noted that as the USG score increases the chance of the case being opened increases and all the opened cases had either 11 or 12, The statistical analysis also shows the difference to be significant with a $\mathrm{p}$ value of 0.001

Among USG factors, a distended GB, increased GB wall thickness, presence of pericholecystic collection, large size of stone proved to be significant and was associated with increased risk of conversion to open cholecystectomy.

Our results demonstrate that an a accurate and easily derived estimation of risk factor predicting conversion from laparoscopic cholecystectomy to open cholecystectomy can be obtained from USG score , increase in score can predict difficulty to be encountered during laparoscopic cholecystectomy and help in making a decision for conversion thus shortening the duration of surgery thereby preventing unnecessary complications.

\section{References}

[1]. Murphy JB. The diagnosis of gallstones. Am Med News 1903:825-833

[2]. Litynski GS. Erich Muhe and the rejection of laparoscopic cholecystectomy (1985): a surgeon ahead of his time. JSLS : Journal of the Society of Laparoendoscopic Surgeons/Society of Laparoendoscopic Surgeons. 1998;2:341-6

[3]. Gutt CN, Encke J, Koninger J, Harnoss JC, Weigand K, Kipfmuller K, et al. Acute cholecystitis: early versus delayed cholecystectomy, a multicenter randomized trial (ACDC study, NCT00447304). Ann Surg. 2013;258:385-93. Takada T, Strasberg SM, Solomkin JS, Pitt HA, Gomi H, Yoshida M, et al. TG13: Updated Tokyo Guidelines for the management of acute cholangitis and cholecystitis. J Hepatobiliary Pancreat Sci. 2013;20:1-7.

[4]. Committee AT, Adler DG, Conway JD, Farraye FA, Kantsevoy SV, Kaul V, et al. Biliary and pancreatic stone extraction devices. Gastrointest Endosc. 2009; 70:603-9

[5]. Yokoe M, Takada T, Strasberg SM, Solomkin JS, Mayumi T, Gomi H, et al. TG13 diagnostic criteria and severity grading of acute cholecystitis (with videos). J Hepatobiliary Pancreat Sci. 2013;20:35-46.

[6]. Pitt HA. Patient value is superior with early surgery for acute cholecystitis. Ann Surg. 2014;259:16-7

[7]. Gupta N, Ranjan G, Arora MP, Goswami B, Chaudhary P, Kapur A, et al. Validation of a scoring system to predict difficult laparoscopic cholecystectomy. Int J Surg. 2013;11:1002-6.

[8]. Vivek MA, Augustine AJ, Rao R. A comprehensive predictive scoring method for difficult laparoscopic cholecystectomy. Journal of minimal access surgery. 2014;10:62-7.

[9]. Strasberg SM, Hertl M, Soper NJ. An analysis of the problem of biliary injury during laparoscopic cholecystectomy. J Am Coll Surg. 1995;180:101-25.

[10]. de Mestral C, Rotstein OD, Laupacis A, Hoch JS, Zagorski B, Alali AS, et al. Comparative operative outcomes of early and delayed cholecystectomy for acute cholecystitis: a population-based propensity score analysis. Ann Surg. 2014;259:10-5. Stromberg C, Nilsson M. Nationwide study of the treatment of common bile duct stones in Sweden between 1965 and 2009 . Br J Surg. 2011;98:1766-74.

[11]. Sheffield KM, Ramos KE, Djukom CD, Jimenez CJ, Mileski WJ, Kimbrough TD, et al. Implementation of a critical pathway for complicated gallstone disease: translation of population-based data into clinical practice. J Am Coll Surg. 2011;212:835-43

[12]. Okamoto S, Nakano K, Kosahara K, Kishinaka M, Oda H, Ichimiya H, et al. Effects of pravastatin and ursodeoxycholic acid on cholesterol and bile acid metabolism in patients with cholesterol gallstones. J Gastroenterol. 1994;29:47-55.

[13]. Lal P, Agarwal PN, Malik VK, Chakravarti AL. A difficult laparoscopic cholecystectomy that requires conversion to open procedure can be predicted by preoperative ultrasonography. JSLS : Journal of the Society of Laparoendoscopic Surgeons/Society of Laparoendoscopic Surgeons. 2002;6:59-63.

[14]. Singh K, Ohri A. Difficult laparoscopic cholecystectomy: a large series from North India. Ind J Surg. 2006;68:205e208

[15]. Nachnani J, Supe A. Pre-operative prediction of difficult laparoscopic cholecystectomy using clinical and ultrasonographic parameters. Indian journal of gastroenterology : official journal of the Indian Society of Gastroenterology. 2005;24:16-8.

[16]. Bjorck M, Bruhin A, Cheatham M, Hinck D, Kaplan M, Manca G, et al. Classification-important step to improve management of patients with an open abdomen. World J Surg. 2009;33:1154-7.

[17]. Coccolini F, Ansaloni L, Manfredi R, Campanati L, Poiasina E, Bertoli P, et al. Peritoneal adhesion index (PAI): proposal of a score for the "ignored iceberg" of medicine and surgery. World journal of emergency surgery : WJES. 2013;8:6.

[18]. Crandall ML, Agarwal S, Muskat P, Ross S, Savage S, Schuster K, et al. Application of a uniform anatomic grading system to measure disease severity in eight emergency general surgical illnesses. Journal of Trauma and Acute Care Surgery. 2014;77:703-8. 
[19]. Kwon YJ, Ahn BK, Park HK, Lee KS, Lee KG. What is the optimal time for laparoscopic cholecystectomy in gallbladder empyema? Surg Endosc. 2013;27:3776-80.

[20]. Pisano M, Ceresoli M, Campanati L, Coccolini F, Falcone C, Capponi MG, et al. Should We must Push for Primary Surgery Attempt in Case of Acute Cholecystitis? A Retrospective Analysis and a Proposal of an Evidence based Clinical Pathway. Emegency Medicine. 2014;4:201.

[21]. Alvarado A. A practical score for the early diagnosis of acute appendicitis. Ann Emerg Med. 1986;15:557-64.

[22]. Randhawa JS, Pujahari AK. Preoperative prediction of difficult lap chole: a scoring method. Indian J Surg. 2009;71:198-201.

[23]. Bouarfa L, Schneider A, Feussner H, Navab N, Lemke HU, Jonker PP, et al. Prediction of intraoperative complexity from preoperative patient data for laparoscopic cholecystectomy. Artif Intell Med. 2011;52:169-76.

[24]. Kama NA, Kologlu M, Doganay M, Reis E, Atli M, Dolapci M. A risk score for conversion from laparoscopic to open cholecystectomy. Am J Surg. 2001;181:520-5.

[25]. Hirota M, Takada T, Kawarada Y, Nimura Y, Miura F, Hirata K, et al. Diagnostic criteria and severity assessment of acute cholecystitis: Tokyo Guidelines. J Hepatobiliary Pancreat Surg. 2007;14:78-82.

[26]. Regimbeau JM, Fuks D, Pautrat K, Mauvais F, Haccart V, Msika S, et al. Effect of postoperative antibiotic administration on postoperative infection following cholecystectomy for acute calculous cholecystitis: a randomized clinical trial. JAMA. 2014;312:145-54.

[27]. Solomkin JS. Clinical trial evidence to advance the science of cholecystectomy. JAMA. 2014;312:135-6. 